\title{
АНАЛИЗ АССОЦИАТИВНОГО ПОЛЯ ЛЕКСЕМ «ДЕРЕВНЯ» В ЛИНГВОКУЛЬТУРОЛОГИЧЕСКОМ АСПЕКТЕ
}

\section{ANALYSIS OF THE ASSOCIATIVE FIELD OF THE LEXEMES "VILLAGE" IN THE LINGUISTIC AND CULTURAL ASPECT}

Cheng Jiaqi

Summary: The article is devoted to the influence of the associative field on the meaning of the lexemes "village" and their dependence on the associative field through analysis in the linguistic and cultural aspect. The analysis of the associative field is given through the study of the historical development of the associative field, which allows us to reveal the features of the creation and consolidation in the history of society.

Keywords: historical material, linguistics, associative field, comparative linguistics, lexemes "village", linguoculturology.
$\mathrm{M}$ ногообразие народов порождает многообразие ассоциативного поля лексем. Не исключением стало и понятие «деревня». Рассматривая его, выявляется свое культурное видение мира, через понимание слова и его значения в прошлом и настоящем. Если обратить внимание на концепт, отраженный в семантике лексем, можно описать само понятие по средствам объективации языка для выявления номинативного поля [2, c.448]. Опорой в проведении анализа лексем «деревня» в данной статье стали словарные толкования языковых единиц.

Рассматривая лексемы «деревня» необходимо обратиться к историческому происхождению слова и всем его значениям [13].

1. Обращая внимание на корень слова, следует отметить родство корня со словом «дерево» дървъня (пашня). Впервые деревнями стали называть участки земли под посадку, очищенные от деревьев и кустарников.

2. Бытуют разные мнения по поводу отношения и родства «деревня» с выкорчевыванием деревьев [1]:

- через глагол «драть» - сдирать кору деревьев; - через «выдирать» растения целиком.

3. Сходным значением будет понятие «пашеть деревню» - место, которое расчищают для посадки.

4. А также производным значением «нива, пашня» обладает слово «druvaz», которое в переводе с латышского языка означает «очищенное место» [10, c.698].

\author{
Чэн Цзяци \\ аспирант, Государственный институт русского языка \\ им. А.С. Пушкина, г. Москва \\ jiaqi.cheng@yandex.ru
}

Аннотация: Статья посвящена влиянию ассоциативного поля на значение лексем «деревня» и их зависимости от ассоциативного поля посредствам анализа в лингвокультурологическом аспекте. Приводится анализ ассоциативного поля через изучение исторического развития ассоциативного поля, позволяющего раскрыть особенности создания и закрепления в истории социума.

Ключевые слова: исторический материал, лингвистика, ассоциативное поле, сопоставительное языковедение, лексемы «деревня», лингвокультурология.

В истории сохранилось много упоминаний лексем «деревня» в период крестьянства и связано с особенностями населенных пунктов и их традиций [4, с.607]. Так, важным фактором выбора места для расчистки под посев было нахождение водоемов неподалеку [6, с.698], чтобы можно было обеспечить полив и в последствии пользоваться водой для обеспечения жизнедеятельности. По этой же причине выбирались формы расположения расчищенных участков (воль поймы реки, вокруг озера и т.д.) [5].

Такое скопление крестьян в дальнейшем образовывало так называемые заселки [11, с.588], преобразующиеся в княжества и вотчины бояр. Причем некоторые из них при большом скоплении превращались в города с крепостями, но для выстраивания ассоциативного поля лексемы «деревня» были использованы следующие источники:

1. Этимологический онлайн-словарь Крылова Г.А.

2. Этимологическом онлайн-словарь Семёнова А.В.

3. Этимологический онлайн-словарь Успенского Л.В.

4. Этимологическом онлайн-словарь Фасмера М.

В истории сохранилось много упоминаний лексем «деревня» в период крестьянства и связано с особенностями населенных пунктов и их традиций [4, с.607]. Так, важным фактором выбора места для расчистки под посев было нахождение водоемов неподалеку [6, с.698], чтобы можно было обеспечить полив и в последствии пользоваться водой для обеспечения жизнедеятельности. По этой же причине выбирались формы располо- 
жения расчищенных участков (воль поймы реки, вокруг озера и т.д.) [5].

Такое скопление крестьян в дальнейшем образовывало так называемые заселки [11, с.588], преобразующиеся в княжества и вотчины бояр. Причем некоторые из них при большом скоплении превращались в города с крепостями, но для выстраивания ассоциативного поля лексемы «деревня» были использованы следующие источники:

1. Этимологический онлайн-словарь Крылова Г.А.

2. Этимологическом онлайн-словарь Семёнова А.В.

3. Этимологический онлайн-словарь Успенского Л.В.

4. Этимологическом онлайн-словарь Фасмера М.

Помимо этого, использовались некоторые русские пословицы и фразеологизмы.

1. Небольшое крестьянское селение.

1) Деревня-колхоз.

2) Территория с угодьями.

3) На околице.

4) Ни к селу, ни к городу; Противопоставление городу.

5) В городе суета, в деревне маета. [7, с.104]

2. Коллективный, общинный образ жизни.

Например, Солдаткиным детям вся деревня отец.

3. Пренебрежительное отношение деревенским обитателям, вызванное стереотипным мышлением.

1) Не мешайся деревенская собака промеж городских.

2) Эка деревенщина в лесу родилась, пенью молилась.

3) Деревенская родня, что зубная боль.

4. Жители, население деревни.

1) Жители деревни.

2) Что знает кум, знает и кумова жена.

3) Было сельцо да сменял на кольцо, было польцо, да за женину ласку сменял на коляску. [3, с.29]
Таким образом, ассоциативное поле лексемы «деревня» в русском языке представляется как село, сельцо [8, с.944], деревенщина, селение, веси, выселки и помогает распознать следующие характеристики:

- где расположен;

- его площадь;

- время препровождение населения и характер;

- структурный состав населения.

Ассоциативное поле лексем «деревня» сочетаются со словами - родина, природа-мать, двор с участком земли [12], огород. А в число лексем помимо вышеупомянутых входят такие слова как: избушка, уютный дом, лесная тишь.

Ассоциациями с лексемами «деревня» являются непосредственно деревенские жители [9]; неквалифицированные работники и загородная местность; непосредственные люди без достаточного образования; замедленное течение жизни, хотя конечно это больше установившиеся мнение, в действительности далекое от реальности.

Следовательно, можно сделать вывод, что анализ ассоциативного поля лексем «деревня» на базе словарных и толковых словарей и исторических данных создает концепт «деревня» как населенная сельская местность с малоэтажными домовыми постройками вне пределов города, с развитием сельского хозяйства и промыслов.

Кроме того, каждая единица лексикона одновременно входит в несколько полей, которые переплетаются и пересекаются друг с другом. Каждая словоформа в памяти человека существует в сочетании с другой или с другими, обычно встречающимися вместе с ней в речи, словоформами.

Ассоциативное поле может включать слова, и связанные между собой не только семантическими, но и словообразовательными отношениями. Ассоциативное поле как модель анализа значения слова имеет важную роль в изучении лингвистики.

\section{ЛИТЕРАТУРА}

1. Абрамов Н. Словарь русских синонимов и сходных по смыслу выражений, 1890, Москва: Русские словари, 1999.

2. Азимов Э.Г., Щукин А.И. Новый словарь методических терминов (теория и практика обучения языкам). - М.: Издательство ИКАР, 2009. 448 с.

3. Алешина Л.Н. Концептологические и лингвокультурологические характеристики национальных ценностей в русской и китайской картинах мира (сопоставительный анализ русских и китайских народных загадок). Вып.1 Сопоставительные исследования 3. -2016. - 29 с.

4. Большая Советская Энциклопедия / гл. ред. А.М. Прохоров, - 3-е изд. - М.: Советская Энциклопедия, 1970 - 1978. Т.7: Гоголь-Дебит. - 1972. - 607 с.

5. Бондарчук, Г.П. Словарь терминов и топонимов М.; географическое описание в 22-х томах «Советский Союз. Российская Федерация» М.«Мысль», 1971.

6. Даль, В.И. Толковый словарь живого и великорусского языка: В 4 т. / В.И. Даль; Предисл.: А.М. Бабкин, В.П. Вамперский.- М.: Рус. яз., 1998 - Т.1: А-3.1998.- 699 c. 
7. Маклакова Е.А. Лингвокультурологические аспекты семантики имени собственного. Язык и национальное сознание. — 2011. Вып. 17. - 104 с.

8. Ожегов, С.И. Толковый словарь русского языка: 80 000слов и фразеологических выражений / С.И. Ожегов, И.Ю. Шведова; Рос. акад. Наук, Ин-т рус.языка им. М.: 000 «ИТИ ТЕХНОЛОГИИ», 2003. - 944 с.

9. Словарь Брокгауза и Ефрона, Петербург: Издательское общество «Ф.А. Брокгауз - И.А. Ефрон», 1907 - 1909.

10. Словарь русского языка: в 4-х т./ Под ред. А.П. Евгеньевой; РАН Ин - т лингвист. исслед. - М.: Рус. яз: Полиграфресурсы, 1999 - Т. 1: А - Й. - 4- е изд., стер. $-1999 .-698$ c.

11. Фасмер, Макс. Этимологический словарь русского языка = Russisches etymolodisches Worterbuch: в 4 т./ М.Фасмер; Пер. с нем. И доп. 0.Н. Трубачева - 4-е изд., стер. - М.: Астрель: АСТ, 2003. Т.1: А-Д: около 4000 слов, 2003. - 588 с.

12. Школьный этимологический словарь русского языка. Происхождение слов. - М.: Дрофа Н.М. Шанский, Т.А. Боброва 2004.

13. Этимологические онлайн словари русского языка. Электронный ресурс. Режим доступа: https://lexicography.online/etymology/д/деревня. [дата обращения: 07.08.2021].

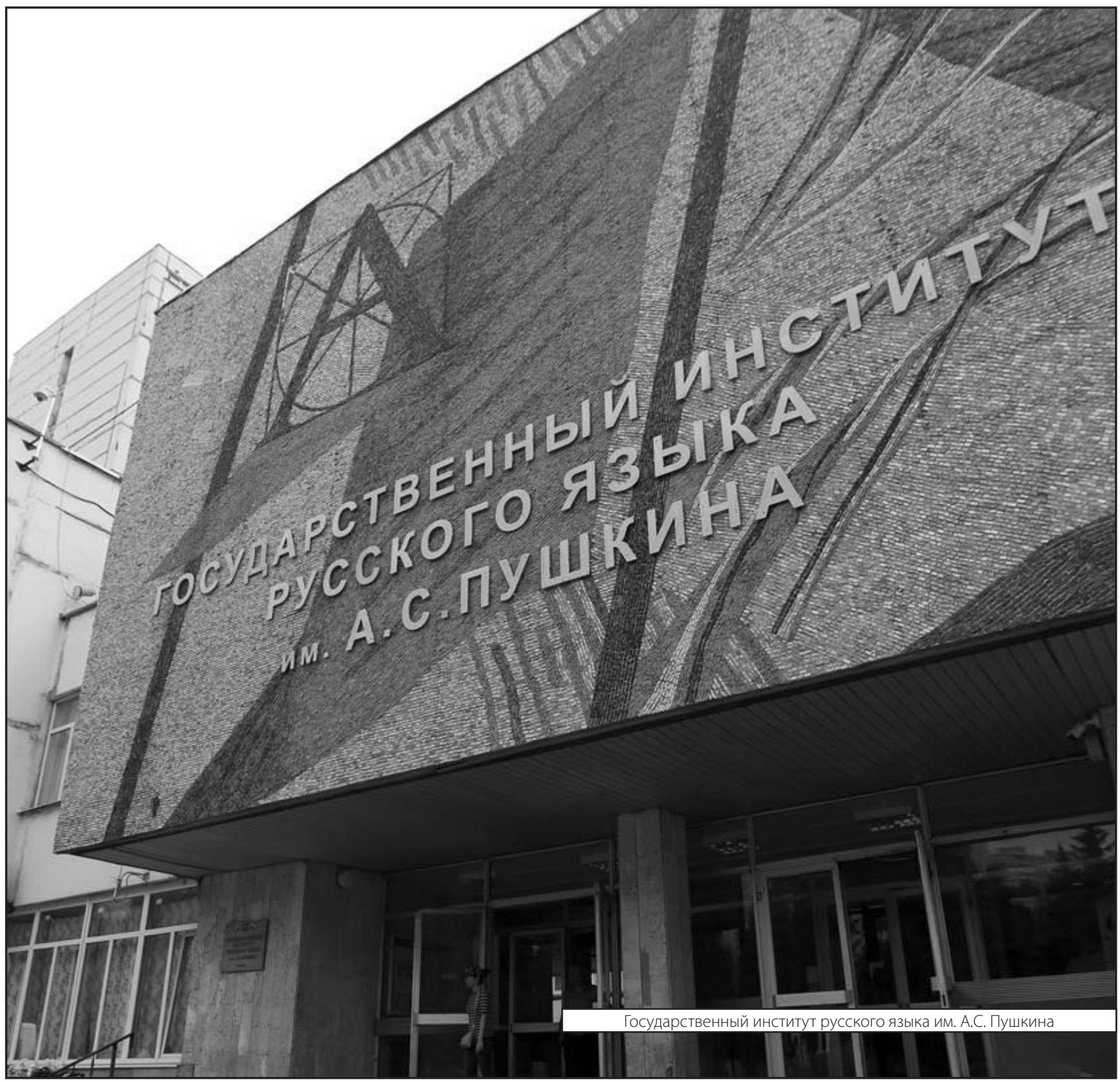

